\title{
Forecasts, Indicators, And Monetary Policy
}

\section{Keith Sill*}

onducting monetary policy is a difficult business. It's easy enough to set a policy goal such as price stability or low and stable inflation, but because monetary policy affects the economy with a lag, achieving those goals requires an ability to peer into the future. A change in the money supply or interest rates today won't affect inflation for months, or even years, down the road. Consequently, policymakers use economic models and forecasts to help them make decisions.

*Keith Sill is a senior economist in the Research Department of the Philadelphia Fed.
Historically, economists and policymakers have used two major approaches to help predict future outcomes. The first approach relies on large-scale statistical models of the economy that capture historical relationships among hundreds of economic variables. The second approach is simpler: focus on small models containing just a few variables, such as money growth and interest rates, that seem to provide information about future output growth, employment, and inflation.

Unfortunately, such models can fail to give reliable predictions, especially when factors affecting the economy change in a major way. Thus, after the oil-price shocks of the 1970s, fore- 
casting models had difficulty predicting the simultaneous occurrence of high unemployment and high inflation. In the 1980s, major changes were made to regulations governing financial institutions, and many models were affected by the breakdown of formerly trusted links between money, inflation, and output growth. When forecasting models become unreliable, policymakers and economists find it more difficult to predict how today's actions will affect the future.

Nature abhors a vacuum in economics no less than in physics. As the old ways of divining the future came under fire, new proposals quickly emerged. Many of these proposals suggested monetary policy be guided by, or even target, certain variables that are sensitive to the market's expectation of inflation, such as commodity prices and interest rate spreads. Perhaps these indicators could give advanced warning if inflation was about to accelerate, allowing policymakers to take steps to ward it off.

Focusing on, or targeting, a small number of expectations-sensitive indicators seems to make life a lot simpler for policymakers. Why bother with complicated economic models or unreliable measures of the money supply if you can act on a few indicators that send good signals about future inflation or output growth? After all, building economic models is difficult, as is trying to understand the causes of inflation and growth.

Unfortunately, there is little reason to believe a monetary policy based primarily on expectations-sensitive forecasting indicators would be successful in the long run. The link between these indicators and economic outcomes is sensitive to many factors in the economy, including the way in which monetary policy is conducted. If policymakers change their method of implementing monetary policy in a substantive way, previously reliable forecasting relationships could easily break down. In addition, market expectations can change for reasons unrelated to future inflation or output growth. A policy focused too closely on expectations-driven indicators could easily be led astray. Another concern is the possibility of bad interaction between market expectations, forecasting indicators, and monetary policy. The result might be self-fulfilling changes in expectations and greater economic instability, precisely the outcome these new approaches seek to avoid. Monetary policy is more likely to succeed if it is guided primarily by variables tied to the underlying causes of inflation and economic growth and not by variables tied to expectations of inflation and growth.

\section{MONETARY POLICY: \\ A FORWARD-LOOKING VENTURE}

Many economists and policymakers are convinced monetary policy can best contribute to maximum sustainable economic growth by delivering a stable price level or low and stable inflation. (See The Benefits of Low and Stable Inflation.) Because monetary policy affects inflation with a lag, policymakers who want to keep inflation low and stable must rely, to some extent, on forecasts or indicators of future inflation. In the 1960s and early 1970s, one standard way of predicting inflation relied on the Phillips curve. The Phillips curve posits a link between the unemployment rate and inflation: when the unemployment rate is low, inflation is high, and when the unemployment rate is high, inflation is low. Before the 1970s, a stable Phillips curve seemed evident in the data. But the relationship broke down following the oil-price shocks and high inflation of the 1970s. ${ }^{1}$

The breakdown of the Phillips curve returned attention to the relationship between money growth and inflation. A key concept for understanding the link between money and inflation is money demand, which links money to prices, interest rates, and output. Individuals and businesses need money to carry on their daily activi-

\footnotetext{
${ }^{1}$ For more on the Phillips curve, see the article by Robert King and Mark Watson. The 1999 article by Thomas Sargent contains a discussion of the breakdown of the Phillips curve in the context of monetary policy.
} 


\section{The Benefits of Low and Stable Inflation}

High and variable inflation hurts economic performance in several ways. ${ }^{a}$ Variable inflation raises the uncertainty faced by debtors and creditors. Loan agreements typically specify an interest rate based on the expected rate of inflation over the life of the loan. If inflation differs from what was expected, so will the real return debtors pay creditors differ from what was expected. Since people generally don't like uncertainty, variable inflation can reduce the flow of credit in the economy. U.S. taxes on interest income and capital gains are not indexed to inflation, so high inflation reduces the after-tax return on saving. As a result, peoples' decisions on how much to save and spend are distorted. And then there's what economists call the "shoe-leather" cost of inflation: the higher the inflation rate, the more time and resources people spend minimizing their holdings of currency and demand deposits; that leaves less effort and fewer resources devoted to productive activity. Price stability avoids these distortions.

Monetary policy in many countries reflects an emerging consensus on these benefits. In the United States, central bankers have emphasized a commitment to price stability as a means to achieve maximum sustainable growth. The governments or central banks of some countries, including the United Kingdom, New Zealand, Sweden, and Canada, have adopted numerical targets for very low to zero inflation. Such goals do not mean policymakers are unconcerned about short-run economic developments. But policymakers recognize that monetary policy affects the economy with a lag, making it impossible to smooth out all short-run fluctuations. Moreover, they realize that sometimes a policy can have beneficial short-term results but unacceptable long-run consequences. ${ }^{\mathrm{b}}$

${ }^{a}$ While some empirical studies, such as the one by Robert Barro, find moderate rates of inflation are inversely related to economic growth, others find no significant correlation between the two (see the paper by McCandless and Weber). However, very high rates of inflation are associated with lower economic growth.

${ }^{\mathrm{b}}$ This conclusion is based on the debate over rules vs. discretion and the time consistency of monetary policies. See chapter 12 in Bennett McCallum's book for a good discussion of discretionary vs. rule-based policymaking. The article by Herb Taylor and the one by Chari, Kehoe, and Prescott discuss time consistency and economic policy.

ties. The amount they wish to hold (demand) depends on the level of interest rates, prices, overall activity in the economy, and the technologies used to make payments. How does the amount of money demanded increase? The more activity there is in the economy, the more transactions are occurring, so people need more money to make purchases. When prices are higher, people need more money to buy the same goods and services. When interest rates are low, people hold more money because the cost of doing so is low. ${ }^{2}$ Evolving payments technologies that allow people to buy and sell without holding cash or checking account balances mean less money is held. The increasingly widespread use of credit cards is one example.

These relationships are summarized by the concept of the velocity of money, a shorthand measure of how many times a year the average dollar changes hands. Velocity plays a key role

\footnotetext{
${ }^{2}$ Currency and demand deposits, a significant portion of the money stock, pay no interest, but nonmonetary assets, such as Treasury bills and bonds, do. The higher interest rates are, the more interest income people forgo by holding currency and demand deposits, so they hold less money. If interest rates decline, people will hold more money.
} 
in the link between money supply growth and inflation:

\section{inflation $=$ money supply growth + growth of velocity - output growth.}

In principle, policymakers can use their knowledge of money velocity to control long-run inflation. If velocity is constant and money grows faster than output, the result is more money chasing the same amount of goods and services in the economy, so prices rise. Too rapid growth in the money supply eventually leads to higher prices and inflation. ${ }^{3}$

However, if money demand moves unpredictably, policymakers can't predict velocity and so are uncertain about the link between growth in the money supply and future inflation. Unfortunately, this appears to be what happened beginning in the 1980s (see Unstable Money Demand and Velocity). Economists Benjamin Friedman and Kenneth Kuttner, focusing on the period since 1975, have shown that the money supply was a useful predictor of the future economy from 1975 until the mid-1980s. But from about the mid-1980s on, they found that the money supply (M1 and M2) had little or no predictive power for future inflation and output. A study by economists Arturo Estrella and Frederic Mishkin, which used the monetary base and M2 as measures of the money supply, came to a similar conclusion. ${ }^{4}$ Estrella and Mishkin looked at data since 1979 and found that the money supply didn't predict future inflation or output well,

\footnotetext{
${ }^{3}$ The story is more complicated than we have made it seem. When the Fed increases the money supply, it does so by purchasing bonds in an open-market operation, which increases bank reserves. Banks then increase lending, which results in more money circulating in the economy. In addition, changes in the money supply are associated with changes in real activity, such as employment and output, at least in the short run.

${ }^{4}$ The monetary base consists of the currency component of the money supply plus bank reserves.
}

and it's not a very good indicator of the stance of monetary policy either. In short, something happened in the 1980s that caused a serious breakdown in the link between money and economic activity.

Why did the breakdown occur? Likely candidates include technological innovation, changing financial regulations, and the financial innovation that both responded to and drove regulatory change. For example, before 1980, banks faced regulatory limits on the interest rates they could pay on certain types of deposits counted in the money supply. In the late 1970s, shortterm interest rates were very high, so consumers were reluctant to hold funds in deposit accounts that didn't pay competitive rates. Banks responded by finding a way to, in effect, pay interest on checking deposits: they created negotiable order of withdrawal (NOW) accounts. Many other financial innovations have occurred over the last 20 years or so, including money market mutual funds, expanded use of credit cards, and widespread use of ATM machines. Financial innovations such as these can have a great impact on money demand and make that demand unstable. ${ }^{5}$

Before the 1980s, simple models that used the growth rate of the money supply to predict future inflation worked fairly well, once they accounted for the oil-price shocks of the 1970s. The instability of money demand in the 1980s meant the models started to have larger-than-usual forecasting errors. In short, the breakdown of the money-demand relationship meant money growth was no longer a reliable variable on which to anchor monetary policy.

\section{IF NOT MONEY GROWTH OR THE PHILLIPS CURVE, WHAT?}

Once it became clear that the simple Phillips curve and growth of the money supply had be-

\footnotetext{
${ }^{5}$ There is an extensive literature on the instability of money demand. See the review article by Stephen Goldfeld and Daniel Sichel.
} 


\section{Unstable Money Demand and Velocity}

The increasing instability of money demand can be easily seen in plots of short-term interest rates and the velocity of money (Figures 1 and 2). Velocity is defined as nominal GDP divided by the money supply. It is a measure of how frequently money changes hands in the economy. When velocity is high, money is turning over rapidly because a relatively small quantity of money suffices to do a year's transactions in goods and services in the economy. Alternatively, low velocity means a relatively large quantity of money is held to buy goods and services, so money must not be changing hands as frequently.

Velocity is positively related to nominal interest rates. When interest rates are high, people tend to reduce money holdings because money generally earns less interest than other assets. With less money held for economywide spending, velocity tends to be high. As long as velocity can be reliably related to interest rates (or other variables), all is well. But if the relationship changes, the Fed will have trouble figuring out how much money to supply to the economy.

For M1, the trends of velocity and interest rates were similar up until the early 1980s: interest rates were generally rising as was velocity. In addition, velocity was not very sensitive to swings in interest rates. The combination made it easy to predict M1 velocity. After that, velocity started to show much wilder swings than before, and even though interest rates came down quite a bit in the 1990s, velocity didn't. The relationship between M2 velocity and interest rates also broke down, though the timing is different. The link between velocity and interest rates held up fairly well until the early 1990s: M2 velocity moved closely with interest rates. After that, M2 velocity increased dramatically at the same time interest rates declined.

The breakdown of the link between velocity and interest rates is a symptom of unstable money demand. Policymakers found the money supply was becoming unreliable in that it did not do well in predicting future economic outcomes.

\section{M1 Velocity and 3-Month T-Bill* Interest Rate}

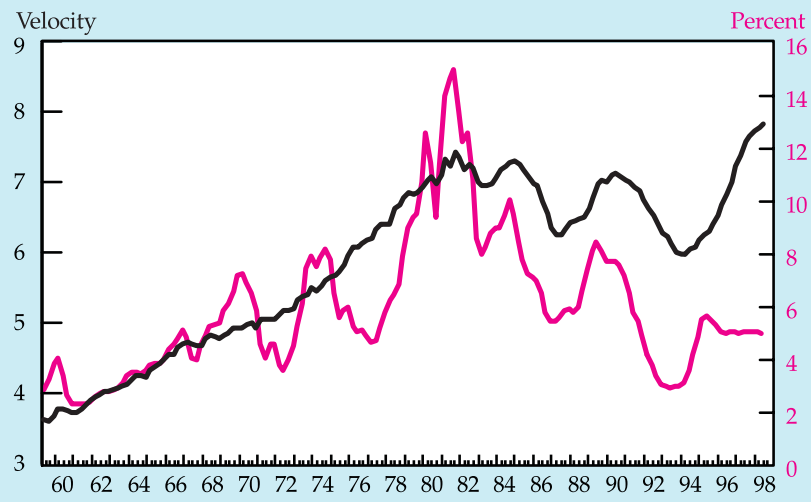

FIGURE 2

M2 Velocity and 3-Month T-Bill* Interest Rate

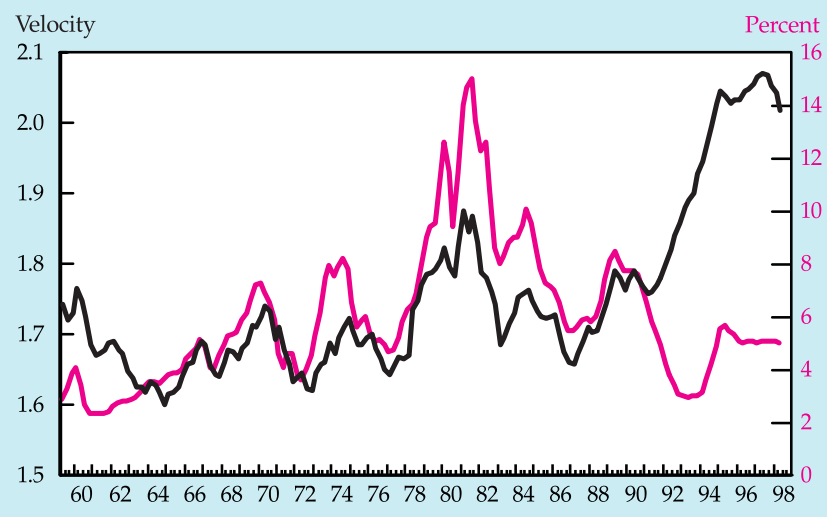

*Two-month moving average 
come increasingly unreliable for setting monetary policy, a search for alternative indicators commenced. In the mid-1980s, inflation averaged about 4 percent, but people retained vivid memories of inflation that exceeded 10 percent in 1979 and 1980. Concerns about inflation were reflected in early suggestions that monetary policymakers try to stabilize commodity prices, an action that, it was argued, would lead to general price stability in the economy. ${ }^{6}$

The notion that monetary policy should stabilize commodity prices or commodity-price indexes met with a good deal of skepticism. Many commodity prices are very volatile and seem to move in response to factors other than movements in the general price level. If policymakers tried stabilizing commodity prices, they would have to respond to sources of volatility that have little to do with inflation. Though the proposal to stabilize commodity prices was flawed, some economists and policymakers argued that commodity prices could still play a useful role in formulating monetary policy. If commodity prices were good predictors of inflation, they might be useful indicators of inflationary pressures in the economy, even if they were not good targets for policy. ${ }^{7}$ After all, a desirable monetary policy is one that responds to inflationary pressures well before actual inflation begins to rise. Perhaps by focusing on other predictors of inflation, rather than variables such as money growth and unemployment, policymakers could better achieve goals of low inflation and longrun price stability.

\footnotetext{
${ }^{6}$ Michael Woodford's article has references to proposals that monetary policy be guided by commodity prices.

${ }^{7}$ Some advocates for using commodity prices to gauge inflationary pressures came from within the Federal Reserve System. See the speeches by Federal Reserve Board governors Wayne Angell, Robert Heller, and Manuel Johnson. In general, the empirical evidence suggests that commodity prices are not very good predictors of inflation. See the article by Michael Woodford for a brief review of the literature and references.
}

EXPECTATIONS, INDICATORS, AND MONETARY POLICY: CAVEATS

Unfortunately, even if a proposed indicator has been a good predictor of inflation, it may not be a good guide for monetary-policy decisions. If the indicator is driven by market expectations of inflation, it may respond to changes in underlying causes of inflation. But it may also respond to other factors, ones unrelated to future inflation. In the latter case, policymakers face greater uncertainty about the signal an indicator gives: false signals are likely.

Suppose policymakers rely on variables, such as the price of gold, that are driven by market expectations about inflation. If expectations about future inflation change, it doesn't matter whether those expectations are well foundedthe price of gold today will change. If many people start to believe inflation will be higher in the future, that belief will be reflected in higher gold prices, even if the fundamentals of the economy are unchanged. Other potential indicators that are sensitive to market expectations are spreads between long-term and short-term interest rates and survey-based measures of inflation expectations. Of course, these variables respond to other economic factors besides changes in inflation expectations. Gold prices respond to discoveries of new gold deposits and extraction techniques and to wars. Interest rate spreads may change in response to financial uncertainties, such as those brought about by the recent Asian crisis. In addition, changes in the way expectations are formed can lead to large swings in expectations-driven indicators.

Pitfalls When Using Expectations-Driven Indicators for Policymaking. Michael Woodford's article discusses several pitfalls for policymakers who focus too narrowly on expectations-driven indicators that have forecasted inflation in the past.

First, as people recognize that monetary policy has shifted its focus to a new set of forecasting indicators, those indicators can become unreliable. The basis for this idea is the Lucas 
critique, named after Nobel Prize-winning economist Robert E. Lucas, who pointed out that the beliefs of households and firms about the conduct of monetary and fiscal policy are important determinants of economic behavior. (See The Lucas Critique.) In making economic decisions, households and firms take into account their beliefs about the course of economic policy and how it will affect them. When policy changes, new beliefs are formed, and economic decisions can then change.

What does this mean for monetary policy? Suppose policymakers announced that henceforth the price of gold will be targeted because gold prices are sensitive to expectations about inflation. Once policy is switched, the old link between gold prices and inflation would almost certainly change, since individuals would buy and sell gold with the knowledge that policymakers are responding to its price. Policymakers would then have to figure out how to interpret the new relationship between gold prices and inflation expectations. The same potential problem would be faced with any variables driven primarily by expectations about inflation or output growth. If policymakers begin to target these variables, it may well happen that their usefulness as forecasters of future in-

\section{The Lucas Critique}

In 1976, Robert Lucas published a now-famous article arguing that the large-scale macroeconomic models then in vogue could, in principle, provide no useful information about the actual consequences of alternative monetary and fiscal policies, even though the models might be very good at short-term forecasting. ${ }^{\text {a }}$ The argument became known as the Lucas critique and has been very influential in macroeconomics.

The core of Lucas's argument is the recognition that expectations about policy are an important ingredient in the behavior of households and firms. Implicit in the estimated large-scale models were a set of beliefs by households and firms about the future course of monetary and fiscal policy. If policies changed substantially, new beliefs would be formed, and households and firms would change their behavior. Thus, it made little sense to use models estimated under one set of beliefs to evaluate the consequences of economic policies that would generate new beliefs and different behavior. Models estimated under the old beliefs would likely give incorrect answers.

One way to think about Lucas's point is in terms of a game: if the rules of the game change, the players will adapt to the new environment by changing their behavior. We can develop an analogy in terms of a football game. ${ }^{b}$ Football fans will have noticed that, during the 1998 season, the Philadelphia Eagles almost always punted when confronted with a fourth down in their own territory. It didn't matter whom the Eagles were playing or where; it was a safe bet they would punt on fourth down when in their own end of the field. On the basis of this history, we would do well to predict that the Eagles would continue to punt on fourth down, and we wouldn't need any understanding of football to be right most of the time. But suppose we want to analyze a change in the rules. The new rules state that teams get six attempts to make a first down. For anyone who understands football, it is clear that our old model, which says the Eagles punt on fourth down, will not predict well in the new environment: the Eagles will change their behavior in response to the new policy.

\footnotetext{
aSee the article "Econometric Policy Evaluation: A Critique."

${ }^{b}$ The football analogy was originally developed in a 1986 article by Thomas Sargent.
} 
flation and growth will change dramatically.

A classic example of this phenomenon is what happened to the Phillips curve in the early 1970s. As discussed earlier, the Phillips curve suggests an inverse link between the unemployment rate and inflation. Before the 1970s, this relationship was apparent in the data. But once policymakers accepted higher inflation to avoid higher unemployment in the 1970s, they found the relationship changed. Households and firms revised their expectations about future inflation as inflation remained high. Expecting higher inflation, workers adjusted their views about the real payoff to working additional hours and about their wage demands; the result was that higher unemployment no longer meant lower inflation. The old link between inflation and unemployment deteriorated when workers changed their beliefs about future inflation. Nowadays, most economists reject the notion of a stable long-run tradeoff between inflation and unemployment.

A second pitfall is that just because a variable doesn't forecast inflation or output growth doesn't mean it should be ignored. An example from outside the world of economics might be helpful. If you step on the gas pedal of a running car, the car will accelerate. But suppose you are in a dual-control car, and whenever you step on the gas, someone sitting next to you steps on the brake. Someone who only sees you pushing on the gas pedal might falsely conclude there isn't much of a relationship between that action and the car's acceleration.

So, too, with economic variables. Suppose accelerating wage growth indicates higher future inflation. If the central bank used tighter monetary policy to offset accelerating wage growth, it would appear as if there were little or no relationship between wage growth and inflation-even though wage growth was an important variable for policymaking. So, a variable may lack forecasting power because it is already being used in making decisions. In that case, it looks as if the variable is not helpful in making forecasts, even though it is tied to subsequent outcomes. In such a case, we would need a detailed statistical model of the underlying relationships in order to uncover the usefulness of the variable.

There is a third pitfall to beware of when using expectations-driven variables to guide monetary policy: the possibility for bad interactions between policy actions and forecasting variables. Expectations could become self-fulfilling, and the economy could become more volatile. Suppose the central bank uses the following policy rule: whenever three-month interest rates rise more than one percentage point above 10-year interest rates, the central bank will increase the growth rate of the money supply, and whenever 10 -year interest rates rise more than one percentage point above three-month interest rates, the central bank will decrease the growth rate of the money supply. This policy might seem sensible, since, in the past, when three-month rates rose well above 10-year rates, the economy often ended up in a recession, and when 10-year rates rose much higher than three-month rates, it often signaled accelerating inflation.

Imagine that for some reason, perhaps an unexpected jump in oil prices, people think there will be a temporary rise in inflation, one that will taper off in the next year or so. The rise in expected inflation causes three-month interest rates to jump up right away; once inflation tapers off, rates are expected to fall back to normal levels. As a result of this expected pattern, threemonth interest rates rise above 10-year interest rates. If policymakers respond too aggressively and pump a lot of money into the economy, the belief that there will be higher inflation could be ratified by substantially higher actual inflation. Thus, the mere expectation of inflation could become self-fulfilling, and the economy could destabilize under this policy rule. The key factor is that interest rate spreads are heavily influenced by expectations. Policymakers may find they are reacting to these expectations in a way that affirms changes in beliefs that aren't tied to economic fundamentals. 


\section{BETTER ECONOMIC MODELS TO THE RESCUE? NOT YET}

The many problems with using expectationsinfluenced forecasting variables to guide monetary policy suggest we shouldn't be too quick to turn away from economic models when trying to understand the behavior of the economy and the implementation of monetary policy. Many economists argue that forecasting models broke down in the 1970s and 1980s because they were not built up from first principles of household and business behavior: they were not sufficiently explicit about the underlying factors governing household choice and business investment. Ideally, the way to assess how forecasting relationships change when policy changes is to have a model that is precise about what causes what in the economy. Such models can trace the effects of policy changes on the economy because they are explicit about the links between variables that cause inflation and growth; the decisions of households, firms, and policymakers; and final outcomes. ${ }^{8}$ Since the models are explicit about the fundamental determinants of economic behavior and the formation of expectations, alternative monetary policies can be fed into the models, and the effects on variables such as inflation, employment, and output growth can be examined. In addition, we could, in principle, trace how expectations-driven variables are affected by alternative policies.

This is a great idea in theory, but where do we get such models? Macroeconomists have been hard at work on models of the economy for quite some time, but there is, as yet, no consensus on models or modeling strategies. ${ }^{9}$ Some economists

\footnotetext{
${ }^{8}$ Robert E. Lucas's 1977 article contains a nontechnical discussion of many of these points.

${ }^{9}$ Much work has been done over the last 20 years on building better foundational models for policy analysis, for example, the paper by Eric Leeper and Christopher Sims, and the book edited by Thomas Cooley. These sources offer examples of what economists call stochas-
}

believe business-cycle fluctuations are driven primarily by demand-side factors, such as the money supply, investment, and consumption. Others attribute business-cycle fluctuations primarily to supply-side factors, such as technological progress. As a result, we have a menu of models from which to choose when investigating the consequences of alternative monetary and fiscal policies. This variety of models may not reveal truth, but it does help us analyze which differences in models are important for generating different predictions about policy responses and outcomes. Different models give us alternative ways to sort out and interpret economic data and allow us to frame questions and investigate implications more clearly.

\section{WHAT CAN POLICYMAKERS DO?}

Absent a reliable link between the money supply and inflation or a completely trustworthy model of the economy, how can a successful policy be implemented? Since the early 1990s, policymakers have found themselves in the position of not having a completely trustworthy indicator for use in setting monetary policy. Despite this, the performance of the economy has been quite good: inflation is low and the economy has been expanding since April 1991.

Economists have investigated an approach that potentially avoids the pitfalls of narrowly focusing on expectations-driven indicators to guide monetary policy: design explicit rules that tell policymakers how to adjust variables they control directly (the federal funds rate or the monetary base) in response to observed deviations of target variables (inflation or nominal

tic, dynamic, general equilibrium models. One key difference between these newer models and older, largescale statistical models is that the newer models have restrictions across equations that account for how people respond to perceived changes in monetary and fiscal policies. In addition, the new models are based explicitly on the utility and profit-maximizing behavior of households and firms. 
GDP) from values policymakers consider desirable. ${ }^{10}$ Such rules are less prone to the problems that arise when people change the way they form expectations. However, these rules can still be adversely affected by a change in the economy that alters the links between the variables policymakers control and the variables they ultimately care about.

Frederic Mishkin, in a 1997 article, argues that many central bankers have been following what he calls the "just do it" strategy, in which preemptive moves are made against inflation and recession. This strategy differs significantly from one that focuses narrowly on a small set of expectations-driven indicators. Under the "just do it" strategy, policymakers pay attention to many economic variables and use a variety of models in an effort to cut off inflationary pressure well before inflation actually increases. They also act to forestall a recession before it begins. There is no clearly articulated, explicit strategy for making monetary policy, but the strategy is coherent nonetheless. The policy is not very transparent, since markets don't know for certain how policymakers are reading the economy at any given moment. But the policy has been pretty successful so far: U.S. inflation is below 2 percent, the unemployment rate is well below 5 percent, and real output has been growing for eight years.

But even under such a strategy, policymakers have to look at economic indicators to judge the stance of monetary policy and assess inflationary pressures. Thus, the warnings we raised about expectations-driven indicators are still important. That is not to say that such indicators are not useful. Policymakers must get a sense of how financial markets expect the future to unfold. However, focusing too narrowly on these variables can quickly lead to the problems enumerated above.

\footnotetext{
${ }^{10}$ We have in mind Taylor's rule and McCallum's rule. See the article by John Taylor and the one by Bennett McCallum for details.
}

Mishkin points out some drawbacks to the "just do it" approach that could lead to trouble in the future. For one, the lack of transparencythe fact that markets can't look at a specific set of indicators and infer how policymakers are reading the economy-could result in greater financial and economic uncertainty. As a result, the economy may not operate as efficiently as it otherwise might. Another drawback is that the success of the "just do it" approach depends on the individuals who make policy decisions. Individual policymakers can differ in their abilities and in their ranking of various policy objectives. Under a "just do it" approach, a change in the persons making policy can more easily lead to a change in economic outcomes.

\section{CONCLUSION}

The fact that monetary policy affects the economy with a lag means that central bankers have to make decisions today based on how they expect policy to affect output and inflation in the future. In assessing the likely consequences of policy actions, policymakers must pay attention to variables tied to the ultimate causes of inflation. In the past, the money supply filled that role, but it became increasingly unreliable as a tool for the conduct of policy. The alternative of focusing on a narrow set of expectationsdriven indicators raises its own set of problems. Forecasting indicators sensitive to expectations can easily lead policy astray and become unreliable when they become the focus of policy.

The best way to understand the interrelationship of monetary policy and forecasting indicators is to develop models of the economy that are explicit about the fundamental determinants of households' and firms' choices about spending and investment. By focusing on variables tied to the fundamental causes of inflation and not solely on expectations-driven variables, monetary policymakers are more likely to achieve the goal of low and stable inflation. Building better models of the economy is an ongoing project for macroeconomists. 
Unfortunately, policymakers do not yet have the luxury of models that closely match the U.S. economy and are always usable for policy analysis. Consequently, the current policy regime is eclectic: policymakers look at many variables and different models to gauge the appropriate stance of policy and the degree of inflationary pressure.

\section{REFERENCES}

Angell, Wayne. "A Commodity Price Guide to Monetary Aggregate Targeting," paper presented to the Lehrman Institute, 1987.

Barro, Robert J. "Inflation and Economic Growth," Bank of England Quarterly Bulletin, 35 (May 1995), pp. 166-76.

Chari V. V, Patrick J. Kehoe, and Edward C. Prescott. "Time Consistency and Policy," in Robert Barro, ed., Modern Business Cycle Theory. Cambridge: Harvard University Press, 1989, pp. 265-305.

Cooley, Thomas F., ed., Frontiers of Business Cycle Research. Princeton: Princeton University Press, 1995.

Estrella, Arturo, and Frederic S. Mishkin. "Is There a Role for Monetary Aggregates in the Conduct of Monetary Policy?" National Bureau of Economic Research Working Paper 5845 (November 1996).

Friedman, Benjamin, and Kenneth N. Kuttner. "A Price Target for U.S. Monetary Policy? Lessons from the Experience with Money Growth Targets," Brookings Papers on Economic Activity, 1 (1996), pp. 77-125.

Goldfeld, Stephen, and Daniel E. Sichel. "The Demand for Money," in B.J. Friedman and F.H. Hahn, eds., Handbook of Monetary Economics. Vol 2. Amsterdam: North-Holland, 1990.

Heller, Robert. "Anchoring the International Monetary System," paper presented to the Heritage Foundation, Washington, D.C. (March 1987).

Johnson, Manuel. “Current Perspectives on Monetary Policy," Cato Journal, 8 (1988), pp. 253-60.

King, Robert G., and Mark W. Watson. "The Post-War U.S. Phillips Curve: A Revisionist Econometric History," Carnegie Rochester Conference on Public Policy, 41 (1994), pp. 157-219.

Leeper, Eric M., and Christopher A. Sims. "Toward a Modern Macroeconomics Model Usable for Policy Analysis," NBER Macroeconomics Annual (1994), pp. 81-118.

Lucas, Robert E. "Econometric Policy Evaluation: A Critique," Carnegie Rochester Conference on Public Policy, 1 (1976), pp. 19-46.

Lucas, Robert E. "Understanding Business Cycles," Carnegie Rochester Conference on Public Policy, 5 (1977), pp. 7-29. 


\section{REFERENCES (continued)}

McCallum, Bennett T. Monetary Economics: Theory and Policy. New York: Macmillan Publishing Co., 1989.

McCallum, Bennett T. "The Case for Rules in the Conduct of Monetary Policy: A Concrete Example," Federal Reserve Bank of Richmond Economic Review, 73 (September/October 1987).

McCandless, George T., and Warren E. Weber. "Some Monetary Facts," Federal Reserve Bank of Minneapolis Quarterly Review (Summer 1995).

Mishkin, Frederic S. "Strategies for Controlling Inflation," National Bureau of Economic Research Working Paper 6122 (August 1997).

Sargent, Thomas J. "Rational Expectations and the Reconstruction of Macroeconomics," in Rational Expectations and Inflation. New York: Harper and Row, 1986, pp. 1-18.

Sargent, Thomas J. "The Temporary (?) Conquest of American Inflation," Web Site Working Paper, 1999.

Taylor, Herbert E. “Time-Inconsistency: A Potential Problem for Policymakers," Federal Reserve Bank of Philadelphia Business Review (March/April 1985).

Taylor, John B. "Estimation and Control of a Macroeconomic Model with Rational Expectations," Econometrica 47 (September 1979), pp. 1267-86.

Woodford, Michael. "Nonstandard Indicators for Monetary Policy: Can Their Usefulness Be Judged from Forecasting Regressions?" in N.G. Mankiw, ed., Monetary Policy. Chicago: University of Chicago Press, 1994. 